\title{
Anthelmintic Activities of Aqueous and Methanol Extracts of Prunella vulgaris L.

\author{
Bashir A Lone ${ }^{1 *}$, Chishti MZ1, Bhat FA², Tak $\mathrm{H}^{2}$, Bandh SA ${ }^{3}$ and Khan $\mathrm{A}^{2}$
}

${ }^{1}$ Parasitology Research Laboratory, Centre of Research for Development, University of Kashmir, Srinagar, Jammu and Kashmir, India ${ }^{2}$ Department of Zoology, University of Kashmir, Srinagar, Jammu and Kashmir, India

${ }^{3}$ Microbiology Research Laboratory, Centre of Research for Development, University of Kashmir, Srinagar, Jammu and Kashmir, India

\begin{abstract}
The increasing anthelmintic resistance, drug residues in animal products and high cost of conventional anthelmintics has created an interest in studying medicinal plants as an alternative source of anthelmintics. The aqueous and methanolic extracts of Prunella vulgaris was evaluated for anthelmintic efficacy against gastrointestinal nematodes of sheep under both in vitro and in vivo conditions using worm motility inhibition assay, egg hatch assay and faecal egg count reduction percent (FECR\%) assay respectively. Crude methanol extract and crude aqueous extract of $P$. vulgaris resulted in mean percentage mortality of $94.44 \%$, as observed after the worms were put in lukewarm PBS for 30 min after exposure to different treatments $(p<0.01)$. Crude methanol extract $\left(L_{50}=2.48 \mathrm{mg} / \mathrm{mL}\right)$ had higher inhibitory effects compared to that of crude aqueous extract $\left(\mathrm{LC}_{50}=3.36 \mathrm{mg} / \mathrm{mL}\right)$ on egg hatching, exhibiting higher ovicidal activity. In vivo, maximum reduction (92.86\%) in faecal egg counts was recorded for crude methanol extract, followed by crude aqueous extract $(80.34 \%)$ with dose $2 \mathrm{~g} / \mathrm{kg}$ of body weight at day 15 post-treatment. The results of the present study suggest that $P$. vulgaris extracts are promising alternatives to the commercially available anthelmintics for the treatment of sheep nematodes.
\end{abstract}

Keywords: Anthelmintic; Prunella vulgaris; Haemonchus contortus; Aqueous extracts; Methanolic extracts

\section{Introduction}

Gastrointestinal parasitism is a significant obstacle in the breeding of sheep, goat and other ruminants [1-3]. Parasitism, especially by helminth species, impairs health by causing lack of appetite, diarrhea, anemia and, in severe cases, death [4]. Synthetic anthelmintics have been used throughout world for decades to minimize the losses caused by helminth infection. However, parasite resistance increases costs, reduces production efficiency along with the risk of contamination of the animal products [5-7] and increases the risk of environmental contamination [8]. These disadvantages have stimulated a search for alternative control methods such as the use of traditional medicinal plants. Screening and proper evaluation of medicinal plants could reveal bioactive compounds that may be sustainable and environmentally acceptable $[9,10]$.

Recently, there has been an increasing interest in ethnomedical and ethnoveterinary practices around the world, especially as they pertain to the use of medicinal plants in treating various ailments [11] and about $80 \%$ of the world population relies on plant origin drugs [12]. For acceptance of medicinal plants into scientific veterinary medicine, it is necessary that their effectiveness and safety be evaluated and confirmed through in vitro and in vivo testing [13].

P. vulgaris L. belonging to family Labiatae, is commonly known as self-heal and is locally known as 'Kalaveath' in Kashmir valley of India. The herb has tremendous medicinal importance and is a single traditional composite unani medicine of sore throat, common cold and head ache is without this herb [14]. The aqueous extract of this herb is recently used in clinical treatment of herpetic keratitis [15]. The herb has great medicinal value and is used as hypotensive, antibiotic, antiseptic, antirheumatic, antipyretic, antibacterial, antioxidant, diuretic and vermifuge $[16,17]$. Chemical analysis of $P$. vulgaris has shown that it is rich in Lupeol, stigma sterol, beta-sitosterol, pentacyclic triterpenoids and sterol glucosides being obtained from the unsaponifiable fraction from the leaves as saponifiable fraction gave lauric, stearic, palmitic, myristic, oleic and linoleic acids.

The above-mentioned reports of medicinal uses of $P$. vulgaris accompanied with the claims of traditional healers for their anthelmintic activity $[14,18]$ made the basis of designing this study for in vitro and in vivo scientific validation of these novel herbs in Kashmir, revealing their anthelmintic activity in combating nematode infections in sheep by local livestock owners and veterinarians.

\section{Materials and Methods}

All animal proceedings were approved by the Ethical Committee of University of Kashmir for animal research (Number: F (Ethical Com. Animal) KU/2012/419.

\section{Collection of plant materials}

The present plant material Prunella vulgaris (Local name Kalaveath) is frequently seen throughout the Kashmir valley in areas of high altitude - wastelands, agricultural lands and on open mountainous slopes, etc. The plant material was collected from Sonamerg area of district Ganderbal, Kashmir (34 17' 04" N, 75 13' 46" E Altitude 10068 ft) during June- August 2010. The mature plant at peak of flowering was collected in polythene bags and was processed by standard technique adopted by KASH (Kashmir University Herbarium). The plant was identified and authenticated by Plant Taxonomist Prof. Irshad Ahmad Nawchoo, Department of Botany, University of Kashmir, Srinagar, India. A voucher specimen (voucher No. 1603) was deposited in KASH (Kashmir University Herbarium). The collected plants were processed for shade drying at the environmental temperatures $\left(25-30^{\circ} \mathrm{C}\right)$ in a wellventilated room. The dried plant parts (leaves, stem and flowers) were milled to a fine powder using an electric stainless steel blender. The powdered plant material was stored in an airtight container/cellophane bags at $4^{\circ} \mathrm{C}$ until extraction.

*Corresponding author: Dr. Bashir A Lone, Parasitology Research Laboratory, Centre of Research for Development, University of Kashmir, Srinagar-190 006, Jammu and Kashmir, India, Tel: +919419384472; E-mail: bashir.lone@gamil.com

Received April 23, 2017; Accepted May 03, 2017; Published May 08, 2017

Citation: Lone BA, Chishti MZ, Bhat FA, Tak H, Bandh SA, et al. (2017)Anthelmintic Activities of Aqueous and Methanol Extracts of Prunella vulgaris L. Nat Prod Chem Res 5: 269. doi: 10.4172/2329-6836.1000269

Copyright: (C) 2017 Lone BA, et al. This is an open-access article distributed under the terms of the Creative Commons Attribution License, which permits unrestricted use, distribution, and reproduction in any medium, provided the original author and source are credited. 


\section{Preparations of methanolic extracts}

Methanolic extracts were prepared by dissolving $500 \mathrm{~g}$ of the powdered plant material in a conical glass percolator to which 1000 $\mathrm{mL}$ (Qualigens) of methanol was added. The plant material was allowed to macerate for $16 \mathrm{~h}$ at room temperature and the percolate was collected by filtering through non-absorbent cotton wool. The process of maceration/percolation was repeated three times. The combined filtrate was evaporated in a vacuum rotary evaporator (R-201, Shanghai Shenshen) under reduced pressure of $22-26 \mathrm{mmHg}$ at $40^{\circ} \mathrm{C}$. The final crude methanol extract $(8.43 \mathrm{~g})$ extract was scrapped off and transferred to a container and kept airtight for storage at $4^{\circ} \mathrm{C}$ until further use.

\section{Preparation of aqueous extracts}

The air dried and coarsely powdered plant material (500 g) was extracted with distilled water in a glass percolator. It was allowed to macerate for $24 \mathrm{~h}$ at room temperature and the brew was filtered using Whatman \#1 filter paper. The process of percolation was repeated three times. The combined filtrate was evaporated in a vacuum rotary evaporator (R-201, Shanghai Shenshen) under reduced pressure of 22$26 \mathrm{mmHg}$ at $40^{\circ} \mathrm{C}$. The final crude aqueous extract $(6.5 \mathrm{~g})$ was scrapped off and transferred to a container and kept airtight for storage at $4^{\circ} \mathrm{C}$ until further use.

\section{In vitro experiment}

Collection of worms and recovery of eggs: Collection of worms and recovery of eggs was done according to the method described by Jabbar et al. [19] and Lone et al. [20]. Briefly, mature live H. contortus female worms were collected from the abomasum of freshly slaughtered sheep then washed and finally suspended in a bottle containing luke warm phosphate buffer saline (PBS) ( $\mathrm{pH}$ 7.2) for further use in adult worm motility assays. For egg hatch test (EHT), some of collected worms were triturated in pestle and mortar and the suspension was filtered through sieve of a 100 -mesh $(150 \mu \mathrm{m}$ pore size $)$. The suspension that passed through the sieve was collected and washed through another size 400 mesh sieve ( $38 \mu \mathrm{m}$ pore size) with warm water. The material left on the sieve was back washed and transferred into Clayton Lane tubes. Filtrate was centrifuged in Clayton Lane tubes for 2 minutes at about $300 \times \mathrm{g}$ and supernatant was discarded. Tubes were agitated to loosen the sediment and then saturated sodium chloride solution was added until a meniscus formed above the tube. A cover slip was placed and sample re-centrifuged for $2 \mathrm{~min}$ at about $130 \times \mathrm{g}$. Cover slip was plucked off carefully from tubes and eggs were washed off into a conical glass centrifuge tube. Tubes were filled with water and centrifuged for $2 \mathrm{~min}$ at about $300 \times \mathrm{g}$. Supernatant was decanted and eggs were re-suspended in water. The eggs were then washed thrice in distilled water and adjusted to 500 eggs $\mathrm{mL}^{-1}$ using Mac Master Egg counting technique [21] for further use in egg hatch test (EHT).

Adult Motility Assay (AMA): In vitro anthelmintic activity of the plant material was evaluated by exposing the adult $H$. contortus to aqueous and methanolic extracts of $P$. vulgaris as described in our earlier work [22]. Twenty adult live and motile female $H$. contortus worms were immediately transferred to the petri dishes containing plant extracts and two petri dishes were also set for controls (Levamisole $0.5 \mathrm{mg} \mathrm{mL}^{-1}$ positive and for $0.95 \%$ phosphate buffer saline as negative control) all the petri dishes were kept for incubation (at $37^{\circ} \mathrm{C}, 100 \%$ relative humidity in a $5 \% \mathrm{CO}_{2}$ /air mixture). Three repetitions with three replicates for each extract concentration and for each control were performed. The inhibition of motility and/or mortality of the worms kept in the above treatments were used as a criterion for anthelmintic activity. The motility was observed after $0,1,2,5$ and $8 \mathrm{~h}$ intervals and post-treatment revival of motility (if any) was observed by keeping the treated worms in the lukewarm fresh PBS for $30 \mathrm{~min}$. The number of worms found dead at $8 \mathrm{~h}$ post-treatment to aqueous and methanolic extracts of $P$. vulgaris were compared to the control group and percentage mortality was calculated by applying formula:

$$
\text { Percent mortality }=\frac{\% \text { test mortality }-\% \text { control mortality }}{100-\% \text { control mortality }} \times 100
$$

Egg Hatch Assay (EHA): Egg hatch assay was conducted according to procedure described by Coles et al. [23]. Approximately, 50 eggs were collected per tube; each tube contained $1 \mathrm{~mL}$ of phosphate buffer saline (PBS) and $1 \mathrm{~mL}$ of increasing concentrations of plant extracts $(75,150$, $300,600,1200$ and $2400 \mu \mathrm{g} / \mathrm{ml}$ ) prepared with phosphate buffer saline (PBS). In addition, levamisole $(0.125 \mathrm{mg} / \mathrm{mL})$ was used as positive control and phosphate buffer saline (PBS) as negative controls. The tubes were covered, and the eggs were incubated for $48 \mathrm{~h}$ at temperature of $27^{\circ} \mathrm{C}$. Thereafter, the number of the first stage larvae $\left(\mathrm{L}_{1}\right)$ present per tube was counted using a dissecting microscope. All the eggs and firststage larvae in three replicates of treatment and control plates were counted. An inhibition percent (\%) of egg hatching was calculated for each extract concentration using the following modified formula of Coles et al.:

$$
\text { inhibition }(\%)=100 \times \frac{1-\mathrm{X} 1}{\mathrm{X} 2}
$$

Where $\mathrm{X} 1$ is the number of eggs hatched in test extracts, and $\mathrm{X} 2$ is the respective number in phosphate buffer saline (PBS) control.

\section{In vivo experiment}

Animals and experimental design: A total 18 Kashmir Marino sheep of both sexes (1 year of age) weighing 18-25 kg having naturally acquired gastrointestinal (GI) nematode infection were selected from the local sheep farm of Sindhbal, Ganderbal, Kashmir. The sheep were pre-adapted to the pen conditions for 20 days prior to the start of the study. Water, hay and feed were provided regularly to the study animals. The study continued for a period of 20 days post-treatments. Before the start of the study, the animals were confirmed positive with an infection of mixed gastrointestinal (GI) nematodes by faecal examination using the standard parasitological procedures applicable to detection of nematode eggs in sheep faeces [21]. Faecal samples were cultured to cultivate the $\mathrm{L}_{3}$ larvae and identified for dependable diagnosis of mixed gastrointestinal (GI) nematode infection in sheep as per the methods of Coles et al. [22]. The sheep $(n=18)$ used for experiment were randomly divided into 6 treatment groups of three animals each on the basis of faecal egg counts (mean \pm S.E. of eggs per gram of faeces) and assigned to different treatments as given below:

Group I: Treated with single dose of crude methanolic extract (CME) @ $1.0 \mathrm{~g} \mathrm{~kg}^{-1}$ body weight (bw)

Group II: Treated with single dose of crude aqueous extract (CAE) @ $1.0 \mathrm{~g} \mathrm{~kg}^{-1}$ body weight (bw)

Group III: Treated with single dose of crude methanolic extract (CME)@ $2 \mathrm{~g} \mathrm{~kg}^{-1}$ body weight (bw)

Group IV: Treated with single dose of aqueous extract (CAE) @ $2 \mathrm{~g}$ $\mathrm{kg}^{-1}$ body weight (bw)

Group V: Treated with single dose of Levamisole @ $7.5 \mathrm{mg} \mathrm{kg}^{-1}$ body weight (bw) as positive control

Group VI: Untreated control.

Each group was isolated from other groups and no physical contact was possible between sheep from different treatment groups, 
anthelmintic effectiveness was assessed as per the guidelines of World Association for the Advancement of Veterinary Parasitology (WAAVP) [23]; revised by Wood et al. [24].

Laboratory procedure: To determine the faecal egg count reductions of gastrointestinal (GI) nematodes in sheep, faecal samples of each animal in the respective treatment groups were collected directly from the rectum in the morning, starting from day 0 and at days 5,10 and 15 post-treatment (PT). The faecal samples were homogenized so that the eggs were uniformly distributed throughout the faeces prior to counting. The total numbers of nematode eggs (faecal egg counts) were determined using Mac Master Egg counting technique [21]; with each egg counted representing 50 eggs per gram of faeces. Faecal egg count percent reduction (FECR \%) was calculated using the formula as described by Lone et al. [25]:

$\mathrm{FECR} \%=\frac{(\text { Pre }- \text { treatment egg count per gram })-(\text { Post }- \text { treatment egg count per gram })}{(\text { Pre }- \text { treatmenteggcount pergram })} \times 100$ (Pre- treatment egg count per gram)

\section{Statistical analyses}

The lethal concentration $50\left(\mathrm{LC}_{50}\right)$ of extract concentration required to prevent $50 \%$ hatching of eggs (in case of egg hatch test) was calculated from the linear regression (for $\mathrm{y}=0$ on the probit scale) by Probit analysis. The data of AMA, fecal egg counts and larval counts was presented as mean \pm standard error of mean [25]. The fecal egg count reduction (FECR) was determined by the method described by Coles et al. [26]. The data from adult mortality test, FECRT and larval counts from various treatments among different days were analyzed ANOVA and compared by the Duncans test $(\mathrm{P}<0.05)$ using the by SPSS 17.0 program

\section{Results}

\section{In vitro anthelmintic activity}

The anthelmintic activities of different concentrations (ranging from $12.50 \mathrm{mg} / \mathrm{mL}$ to $50 \mathrm{mg} / \mathrm{mL}$ ) of crude aqueous and methanolic extracts of $P$. vulgaris were determined against adult $H$. contortus and recorded as percent mortality (Table 1 ). Worm mortality varied significantly $(\mathrm{p}<0.01)$ among concentrations and test extracts and among exposure periods. Control mortality was significantly lower $(p<0.01)$ than that recorded for any of the test concentrations. Mortality increased over time (post-exposure) and due to ascending concentrations. After 8th h exposure the highest tested concentration of $50 \mathrm{mg} / \mathrm{mL}$, resulted in $75 \%$ mortality, being the highest value. The $\mathrm{CME}$ and CAE of $P$. vulgaris resulted in mean percentage mortality of $94.44 \%$, as observed after the worms were put in lukewarm PBS for 30 min after exposure to different treatments. Further, there was $100 \%$ mortality of worms in levamisole (used as a reference drug) within $4 \mathrm{~h}$ PE. There was no mortality of worms kept in PBS till $8 \mathrm{~h}$ PE.

\section{Egg hatch test}

Egg hatch Inhibition for $H$. contortus exposed to methanolic extracts of Prunella vulgaris was less compared to levamisole. Crude methanolic extract $\left(\mathrm{LC}_{50}=2.48 \mathrm{mg} / \mathrm{mL}\right)$ was found to has higher inhibitory effects compared to that of aqueous extract $\left(\mathrm{LC}_{50}=3.36 \mathrm{mg} / \mathrm{mL}\right)$ on egg hatching. Correlation of regression of the data revealed a dose dependent response of extracts for aerial parts. The regression values and correlation of coefficient of extracts and levamisole (positive control) were $\mathrm{y}=-$ $0.0001 x+6.4026, \mathrm{R}^{2}=0.7454$ and $\mathrm{y}=-0.2159 \mathrm{x}+6.2447, \mathrm{R}^{2}=0.775$ (Table 2). However, ovicidal activities of $P$. vulgaris plant was lower than that of positive control.

\section{In vivo anthelmintic activity}

Faecal egg count reduction test: For nematodes, levamisole at the recommended dosage resulted in $98.56 \%$ reduction in mean faecal egg counts, whereas for methanolic extract of $P$. vulgaris at the dose levels of 1 $\mathrm{g} / \mathrm{kg}$ bw and $2 \mathrm{~g} / \mathrm{kg}$ bw resulted in faecal egg counts reduction of $81.47 \%$ and $92.86 \%$, respectively (Table 3 ). All groups had positive reduction in mean faecal egg counts compared to the negative control after day 15. In the control group treated with aqueous extract of $P$. vulgaris, mean undifferentiated faecal egg count values were fairly steady throughout the period of observation, with arithmetic means varying from 1212.5 \pm 4.3 on day 0 (Pretreatment) post-treatment to $480.0 \pm 14.4$ on day 15 post-treatment.

\section{Discussion}

Pharmaceutical and scientific communities have recently received the attention of the medicinal plants being used as herbal remedies and shown them to be generally safe with fewer side effects if used in the proper therapeutic dosages [27]. Various phytochemical constituents viz., alkaloids, saponins, tanins and phenolic acids have been isolated from P. vulgaris [28] which either in isolation or in combination may be responsible for the anthelmintic activity $[29,30]$. Evidence in support of the direct effect of condensed tannin was provided by Niezen et al. [31] and Molan et al. [32] who demonstrated that the condensed tannins extracted from $L$. pedunculatus, $L$. corniculatus, H. coronarium, and $O$. viciifolia forages reduced the rate of larval development (eggs to $\mathrm{L}_{3}$ larvae) by $91 \%$, reduced the number of eggs hatching by $34 \%$, and decreased the mobility of $\mathrm{L}_{3}$ larvae by $30 \%$. A number of showed that reductions in egg excretion disappeared when CT-administration was stopped [33-35], thereby suggesting that CTs temporally reduced the female worm fecundity. In addition, the presence of phenolic compounds indicates the role of antimicrobial agents [36]. This might be the reason that traditional healers in Kashmir prescribe steam inhalation of this herb to clear phlegm from chest and brain cavity, hence reducing chest infections and head ache.

The present data clearly show that $P$. vulgaris is effective against $H$. contortus as is evident from FECR rate and percent mortality of $H$. contortus. On comparing the methanolic and aqueous extracts, highest FECR rate $(92.86 \%)$ was found by administration of methanolic extract at day 15 and (80.34\%) in aqueous extract on the same day. This result could be explained by the fact that the methanolic extracts possess several chemical compounds, and many of them could display ovicidal action. The present study reveals that methanolic extracts had good in vitro and in vivo anthelmintic activity and this could be due to the presence of a higher concentration of the alcohol-soluble active molecule(s) in the extract, also revealed by Iqbal et al. [30]. The latter further also opined that Neem (Azadirachtaindica, Meliaceae) crude methanolic seed extract moderately reduced EPG in sheep infected with Haemonchus and Trichostrongylus, while feeding fresh leaves to infected sheep significantly reduced worm burden caused by Haemonchus, Trichostorngylus, and Oesophagostomum, but showed no effect for EPG reduction as suggested by Chandrawathani et al. [37]. The total action of the extracts is a sum of the activities of their constituents [13]. It has been speculated that the anthelmintic activity of aqueous extracts of Prunela vulgaris against $H$. contortus may be due to presence of excessive phenolic compounds, as reported by Adedapo et al. [38]. They also maintained that aqueous extract of Euphorbia hirta contained excessive phenolic compounds when used to treat dogs infected with Ancylostomacaninum, Toxocaracanis, Dipylidiumcaninum and Echinococcus. Moreover, as is evident from the experiments, $P$. vulgaris was able to kill $H$. contortus in both in vitro and in vivo studies. In vitro studies showed highest nematode motility (100\%) in the higher concentrations of methanolic extract $\left(50 \mathrm{mg} \mathrm{mL}^{-1}\right)$ rather 


\begin{tabular}{|c|c|c|c|c|c|}
\hline \multirow{2}{*}{ Treatment } & \multicolumn{5}{|c|}{ Mean \pm SEM of number of Haemonchus contortus worms showing percent motility (percent mortality) } \\
\hline & $\mathbf{O} \mathbf{h}$ & $1 \mathrm{~h}$ & $2 \mathrm{~h}$ & $5 \mathrm{~h}$ & $8 \mathrm{~h}$ \\
\hline Crude aqueous extract $50 \mathrm{mg} / \mathrm{mL}$ & $20 \pm 00$ & $8 \pm 1.2(60.00)$ & $5 \pm 0.0(75.00)$ & $3 \pm 1.9(85.50)$ & $0 \pm 0.1(100.00)$ \\
\hline Crude aqueous extract $25 \mathrm{mg} / \mathrm{mL}$ & $20 \pm 00$ & $10 \pm 0.9(50.00)$ & $8 \pm 0.6(60.00)$ & $7 \pm 0.9(65.50)$ & $3 \pm 0.5(85.00)$ \\
\hline Crude aqueous extract $12.5 \mathrm{mg} / \mathrm{mL}$ & $20 \pm 00$ & $11 \pm 1.2(45.50)$ & $9 \pm 1.3(55.00)$ & $7 \pm 1.8(65.00)$ & $5 \pm 0.5(75.00)$ \\
\hline Crude methanolic extract $50 \mathrm{mg} / \mathrm{mL}$ & $20 \pm 00$ & $6 \pm 1.2(70.00)$ & $3.50 \pm 0.9(85.00)$ & $20 \pm 00(100.00)$ & $20 \pm 00(100.00)$ \\
\hline Crude methanolic extract $25 \mathrm{mg} / \mathrm{mL}$ & $20 \pm 00$ & $8 \pm 1.0(60.00)$ & $6 \pm 0.3(70.00)$ & $4 \pm 0.9(80.00)$ & $1 \pm 0.7(95.00)$ \\
\hline Crude methanolic extract $12.5 \mathrm{mg} / \mathrm{mL}$ & $20 \pm 00$ & $9 \pm 0.9(55.00)$ & $8 \pm 0.3(60.00)$ & $6 \pm 1.2(70.50)$ & $2 \pm 1.7(80.50)$ \\
\hline Levamisole (positive control) $0.55 \mathrm{mg} / \mathrm{mL}$ & $20 \pm 00$ & $3 \pm 00(64.00)$ & $20 \pm 00(100.00)$ & $20 \pm 00(100.00)$ & $20 \pm 00(100.00)$ \\
\hline PBS (negative control) $0.9 \%$ & $20 \pm 00$ & $20 \pm 00$ & $20 \pm 00$ & $20 \pm 00$ & $18 \pm 00$ \\
\hline
\end{tabular}

Table 1: In vitro anthelmintic efficacy of crude extracts of Prunella vulgaris L. on Haemonchus contortus.

\begin{tabular}{|c|c|c|}
\hline Treatment & LC $_{50}$ & Regression values and correlation of regression \\
\hline Methanolic extract of $P$. vulgaris & 2.48 & $y=-0.000 \mid x+6.4026, R^{2}=0.7454$ \\
\hline Aqueous extract of $P$. vulgaris & 3.36 & $y=-0.0003 x+6.7332, R^{2}=0.9136$ \\
\hline Levamisole & 1.88 & $y=-0.2159 x+5.2447, R^{2}=0.6475$ \\
\hline
\end{tabular}

Table 2: Regression values and correlation of regression of the effect of different extracts of Prunella vulgaris L. on egg hatching of Haemonchus contortus.

\begin{tabular}{|c|c|c|c|c|c|}
\hline \multirow{3}{*}{ Treatment } & \multirow{3}{*}{ Fraction } & \multicolumn{4}{|c|}{ Mean \pm SEM of eggs per gram of faeces pre- and post-treatment (percent reduction in egg count) } \\
\hline & & \multirow{2}{*}{ Pre-treatment Day 0} & \multicolumn{3}{|c|}{ Post-treatment } \\
\hline & & & Day 5 & Day 10 & Day 15 \\
\hline \multirow{2}{*}{$\begin{array}{c}\text { Group I and II } \\
P . \text { vulgaris } 1 \mathrm{~g} / \mathrm{kg} \mathrm{bw}\end{array}$} & Methanol & $1450.0 \pm 35.4^{\mathrm{a}}$ & $610.0 \pm 20.4^{\mathrm{b}}(57.93)$ & $544.0 \pm 20.4^{c}(62.48)$ & $268.6 \pm 16.6^{\mathrm{d}}(81.47)$ \\
\hline & Aqueous & $1212.5 \pm 4.3^{\mathrm{a}}$ & $910.5 \pm 3.6^{b}(24.87)$ & $793.50 \pm 1.4^{c}(34.52)$ & $480.0 \pm 14.4^{\mathrm{d}}(60.39)$ \\
\hline \multirow{2}{*}{$\begin{array}{c}\text { Group III and IV } \\
P . \text { vulgaris } \\
2 \mathrm{~g} / \mathrm{kg} \mathrm{bw}\end{array}$} & Methanol & $742.6 \pm 2.92^{\mathrm{a}}$ & $282.6 \pm 1.7^{\mathrm{b}}(61.94)$ & $226.3 \pm 10.05^{\mathrm{b}}(69.52)$ & $53.0 \pm 2.5^{\mathrm{d}}(92.86)$ \\
\hline & Aqueous & $1287.00 \pm 7^{a}$ & $760.00 \pm 2.6^{b}(40.94)$ & $610.00 \pm 1.7^{c}(52.60)$ & $252.90 \pm 2.4^{d}(80.34)$ \\
\hline $\begin{array}{l}\text { Group V Levamisole } \\
\text { (Positive control) }\end{array}$ & - & $880.4 \pm 10.0^{\mathrm{a}}$ & $60.8 \pm 12.37^{\mathrm{b}}(93.09)$ & $31.6 \pm 20.46^{c}(96.41)$ & $12.6 \pm 0.25^{d}(98.56)$ \\
\hline $\begin{array}{l}\text { Group VI Untreated } \\
\text { (Negative control) }\end{array}$ & - & $682.6 \pm 4.95^{\mathrm{a}}$ & $697.6 \pm 2.92^{\mathrm{b}}$ & $705.0 \pm 2.79^{c}$ & $742.6 \pm 3.93^{d}$ \\
\hline
\end{tabular}

SEM=Standard error of mean; bw=Body weight; Different letters indicate significantly different values $(P<0.05)$

Table 3: Mean faecal egg counts and percentage reduction in egg counts for Prunela vulgaris L. extracts-treated sheep compared with untreated controls.

than in aqueous extracts of the same concentration. It is possible that tannins contained in the extracts of Prunela vulgaris produce similar effects causing death of $H$. contortus worms in in vitro studies, a fact also maintained by Kane et al. [29] and Tariq et al. [39]. Larvicidal and ovicidal effects of some plants have also been reported earlier against H. contortus eggs and larvae [11,25,40-43]. Amarante et al. [44] found that species of GI nematodes resistant to articular anthelmintic drugs showed higher $\mathrm{ED}_{50} / \mathrm{LC}_{50}$ value than susceptible species. The present study, however, confirmed the anthelmintic activity of $P$. vulgaris against nematode parasites. As per the World Association for Advancement of Veterinary Parasitology (WAAVP) guidelines, a FEC reduction of $99 \%$ or higher is considered to be highly efficacious, whereas an $80 \%$ or around is just adequate [45]. While considering these guidelines it can be inferred that $P$. vulgaris do possess adequate anthelmintic activities.

\section{Conclusions}

From the above results, it is concluded that $P$. vulgaris used, traditionally to treat intestinal worm infections, showed significant anthelmintic activity [46]. The experimental evidence obtained in case of $H$. contortus could provide a rationale for the traditional use of this plant as anthelmintic. Moreover, quality controlled extracts or possibly isolated bioactive compounds could be a promising alternative to conventional anthelmintics for the control of GIP in small ruminants in future [47]. However, the mechanisms of their effectiveness still remain to be tested in vivo. For this purpose, safety and toxicity studies must be conducted in vivo to determine the minimum non- lethal concentrations needed for the treatment of nematode infections [48].

\section{Conflict of Interest Statement}

The authors declare no conflicts of interest. Equipment brands, chemicals, and other trade names are mentioned here solely for the convenience of the reader and imply no endorsement by the authors.

\section{Acknowledgements}

We acknowledge the financial support from Department of Science and Technology, Govt. of India, New Delhi. We also appreciate the technical assistances of the CORD technical staff for their valuable assistance with the initial Haemonchus contortus cultures (Microbiology Lab). The authors would like to express their sincere thanks to the Director of the Centre Prof. Azra N Kamili, for providing the necessary facilities, and Prof. Irshad A Nawchoo, Head Department of Botany for the taxonomic confirmation of the plant species used in this study and to Prof. AK Pandit for his sound advice and help in drafting manuscript.

\section{References}

1. Anderson RM, May RM (1979) Population biology of infectious diseases: Part II. Nature 280: 361-367.

2. Daszak P, Cunningham AA, Hyatt AD (2000) Wildlife Ecology-Emerging infectious diseases of wildlife-threats to biodiversity and human health. Science 287: 443-449.

3. Pessoa LM, Morais SM, Bevilaqua CM, Luciano JHS (2002) Anthelmintic activity essential oil of Ocimun gratissimum Linn. and eugenol against Haemonchus contortus. Veterinary Parasitology 109: 59-63.

4. Athanasiadou S, Kyriazakis I (2004) Plant secondary metabolites: antiparasitic effects and their role in ruminant production systems. Proc Nutr Soc 63: 631-639.

5. Waller PJ (1994) The development of anthelmintic resistance in ruminant livestock. Acta Trop 56: 233-243.

6. Dewanjee S, Maiti A, Kundu M, Mandal SC (2007) Evaluation of anthelmintic activity of crude extracts of Diospyros peregrine, Coccinia grandis and Schima wallichii. Dhaka University Journal Pharmaceutical Science 6: 121-123.

7. Saddiqi HA, Iqbal Z, Khan MN, Muhammad G (2010) Comparative resistance 
of sheep breeds to Haemonchus contortus in a natural pasture infection. International Journal of Agriculture and Biology 12: 739-743.

8. Hammond JA, Fielding D, Bishop SC (1997) Prospects for plant anthelmintics in tropical veterinary medicine. Veterinary Research Communication 21: 213-228.

9. Eguale T, Tilahun G, Debella A, Feleke A, Makonnen E (2007) In vitro and in vivo anthelmintic activity of crude extracts of Coriandrum sativum against Haemonchus contortus. Journal of Ethnopharmacology 110: 428-433.

10. Nisa H, Kamili AN, Amin S, Bandh SA, Lone BA, et al. (2013) Antimicrobia and antioxidant activities of alcoholic extracts of Rumex dentatus L. Microbial Pathogenesis 57: 17-20

11. Bizimenyera ES, Githiori JB, Eloff JN, Swan GE (2006) In vitro activity of Peltophorum africanum Sond. (Fabaceae) extracts on the egg hatching and larval development of the parasitic nematode Trichostrongylus colubriformis. Veterinary Parasitology 142: 336-343.

12. Sarin YK (1996) Illustrated manual of herbal drug used in ayurveda. New Delhi: CSIR and ICMR, Niscom.

13. Rates SMK (2001) Plants as source of drugs. Toxicon 39: 603-613.

14. Kaul MK (1997) Medicinal plants of Kashmir and Ladakh, temperate and coldarid Himalaya. Indus Publishing Co., New Delhi, India, p: 173.

15. Xu H, Lee SHS, Lee SF, White RL, Blay J (1999). Isolation and Characterization of an anti-HIV polysaccharide from Prunella vulgaris. Antiviral Research 44: 43-54.

16. Duke JA, Ayensu ES (1985) Medicinal Plants of China. Reference Publications Michigan, USA.

17. Khare CP (2007) Indian Medicinal Plants - An Illustrated Dictionary. SpringerVerlag Berlin/Heidelberg, p: 436.

18. Khan ZS, Khuroo AA, Dar GH (2004) Ethnomedicinal survey of Uri, Kashmir Himalaya. Indian Journal of Traditional Knowledge 3: 351-357.

19. Jabbar A, Zaman MA, Iqbal Z, Yaseen M, Shamim A (2007) Anthelmintic activity of Chenopodium album (L.) and Caesalpinia crista (L.) against Trichostrongylid nematodes of sheep. Journal of Ethnopharmacology 114: 86-91.

20. Lone BA, Bandh SA, Chishti MZ, Bhat FA, Tak H, et al. (2013) Anthelmintic and Antimicrobial Activity of Methanolic and Aqueous extracts of Euphorbia helioscopia L. Tropical Animal Health and Production 45: 743-749.

21. Soulsby EJL (1982) Helminths Arthropods and Protozoa of Domesticated Animals. The English Language Book Society and Bailliere Tindall, 7th edn. London, UK, pp: 763-773.

22. Coles GC, Jackson F, Pomroy WE, Prichard RK, Von Samson- Himmelstjerna $\mathrm{G}$, et al. (2006) The detection of anthelmintic resistance in nematodes of veterinary importance Review. Veterinary Parasitology 136: 167-185.

23. Powers KG, Wood IB, Eckert J, Gibson T, Smith HJ (1982) World Association for the Advancement of Veterinary Parasitology (WAAVP) guidelines for evaluating the efficacy of anthelmintics in ruminants (bovine and ovine). Veterinary Parasitology 10: 265-284.

24. Wood IB, Amaral NK, Bairden K, Duncan JL, Kassai T, et al. (1995) World Association for the Advancement of Veterinary Parasitology (WAAVP). Second edition of guidelines for evaluating the efficacy of anthelmintics in ruminants (bovine, ovine, caprine). Veterinary Parasitology 58: 181-213.

25. Lone BA, Chishti MZ, Bhat FA, Tak H, Bandh SA (2012) In vitro and In vivo Anthelmintic Activity of Euphorbia helioscopia L. Veterinary Parasitology 189: 317-321.

26. Coles GC, Bauer C, Borgsteede FHM, Geerts S, Klei TR, et al. (1992) World Association for the Advancement of Veterinary Parasitology (WAAVP) methods for the detection of anthelmintic resistance in nematodes of veterinary importance. Veterinary Parasitology 44: 35-44.

27. Hanrahan CG (2001) Encyclopedia of Alternative Medicine.

28. Rasool R, Ganai BA, Akbar S, Kamili AN, Masood A (2010) Phytochemical Screening of Prunella Vulgaris L. - An Important Medicinal Plant of Kashmir. Pakistan Journal of Pharmaceutical Science 23: 399-402.

29. Kane SR, Mohite SK, Shete JS (2009) Antihelmintic Activity of Aqueous and Methanolic Extracts of Euphorbia thymifolia Linn. International Journal of Pharm Tech Research 1: 666-669.

30. Iqbal Z, Sarwar M, Jabbar A, Ahmed S, Nisa M, et al. (2007) Direct and indirect anthelmintic effects of condensed tannins in sheep. Veterinary Parasitology 144 $125-131$
31. Niezen JH, Waghorn GC, Charleston WAG (1998) Establishment and fecundity of Ostertagia circumcincta and Trichostrongylus colubriformis in lambs fed Lotus (Lotus pedunculatus) or perennial rye grass (Lolium perenne) Veterinary Parasitology 78: 13-21.

32. Molan AL, Waghorn GC, Min BR, Me Nabb WC (2000) The effect of condensed tannins from seven herbages on Trichostrongylus colubriformis larval migration in vitro. Folia Parasitologica 47: 39-44.

33. Min BR, Hart SP (2003) Tannins for suppression of internal parasites. Journal of Animal Science 81: 102-109.

34. Lange KG, Olcott DD, Miller JE, Mosjidis JA, Ternll TH, et al. (2006) Effect of Sencea lespedeza (Lespedeza cuneata) fed as hay, on natural and experimental Haemonchus contortus infections in lambs. Veterinary Parasitology 141: $273-278$

35. Athanasiadou S, Kyriazakis I, Jackson F, Coop RL (2000) Effect of shortterm exposure to condensed tannins on adult Trichostrongylus colubriformis Veterinary Record 146: 728-732.

36. Okwu DE, Okwu ME (2004) Chemical composition of Spondia smombin Lin. plant parts. Journal of Sustainable Agricultural Environment 62: 140-147.

37. Chandrawathani P, Chang KW, Nurulaini R, Waller PJ, Adnan M, et al. (2006) Daily feeding of fresh Neem leaves (Azadirachta indica) for worm control in sheep. Tropical Biomedicine 23: 23-30.

38. Adedapo AA, Shabi OO, Adedokun OA (2005) Anthelmintic efficacy of the aqueous crude extract of Euphorbia hirta Linn in Nigerian dogs. Veterinarski Arhiv 75: 39-47.

39. Tariq KA, Chishti MZ, Ahmad F, Shawl AS (2009) Anthelmintic activity of extracts of Artemisia absinthium against ovine nematodes. Veterinary Parasitology 160 : 83-88

40. Assis LM, Bevilqua CML, Morais SM, Vieira LS, Costa CTC, et al. (2003) Ovicidal and larvicidal activity in vitro of Spigelia anthelmia Linn. extracts on Haemonchus contortus. Veterinary Parasitology 117: 43-49.

41. Hordegen P, Cabaret J, Hertzberg H, Langhans W, Maurer V (2006) In vitro screening of six anthelmintic plant products against larval Haemonchus contortus with a modified methyl-thiazolyl-tetrazolium reduction assay. Journal of Ethnopharmacology 108: 85-89.

42. Hordegen P, Hertzberg H, Heilmann J, Langhans W, Maurer V (2003) The anthelmintic efficacy of five plant products against gastrointestinal trichostrongyloids in artificially infected lambs. Veterinary Parasitology 117: 51-60.

43. Maciel MV, Morais SM, Cevilaqua ML, Camurca-Vasconcelo ALF, Costa CTC et al. (2006) Ovicidal and larvicidal activity of Meliaazed arach extracts on Haemonchus contortus. Veterinary Parasitology 140: 98-104.

44. Amarante AFT, Pomroy WE, Charleston WAG, Leathwick DM, Torneros MTT (1996) Evaluation of a larval development assay for the detection of anthelmintic resistance in Ostertagia circumcincta. International Journal of Parasitology 27 305-311.

45. Githiori JB, Athanasiadou S, Thamsborg SM (2006) Use of plants in nove approaches in control of gastrointestinal helminthes in livestock with emphasis on small ruminants. Veterinary Parasitology 139: 308-320.

46. Donald AD (1994) Parasites, animal production and sustainable development. Veterinary Parasitology 54: 27-47

47. Girach RD, Khan H, Ahmad M (2003) Botanical identification of Thuhar, seldom used as Unani medicine. Hamdard Med 46: 27-33.

48. Varady M, Corba J (1999) Comparison of six in vitro tests in determining benzimidazole and levamisole resistance in Haemonchus contortus and Ostertagia circumcincta of sheep. Veterinary Parasitology 80: 239-249. 